\title{
Photosynthetic responses of Emiliania huxleyi to UV radiation and elevated temperature: roles of calcified coccoliths
}

\author{
K. Xu${ }^{1}$, K. Gao ${ }^{1}$, V. E. Villafañe ${ }^{2}$, and E. W. Helbling ${ }^{2}$ \\ ${ }^{1}$ State Key Laboratory of Marine Environmental Science, Xiamen University, Xiamen, 361005, China \\ ${ }^{2}$ Estación de Fotobiología Playa Unión and Consejo Nacional de Investigaciones Científicas y Técnicas (CONICET), \\ Casilla de Correos No. 15, 9103 Rawson, Chubut, Argentina
}

Received: 2 January 2011 - Published in Biogeosciences Discuss.: 1 February 2011

Revised: 16 May 2011 - Accepted: 24 May 2011 - Published: 6 June 2011

\begin{abstract}
Changes in calcification of coccolithophores may affect their photosynthetic responses to both, ultraviolet radiation (UVR, 280-400 nm) and temperature. We operated semi-continuous cultures of Emiliania huxleyi (strain CS-369) at reduced $(0.1 \mathrm{mM}, \mathrm{LCa})$ and ambient $(10 \mathrm{mM}$, $\mathrm{HCa} \mathrm{Ca}^{2+}$ concentrations and, after 148 generations, we exposed cells to six radiation treatments $(>280,>295,>305$, $>320,>350$ and $>395 \mathrm{~nm}$ by using Schott filters) and two temperatures $\left(20\right.$ and $\left.25^{\circ} \mathrm{C}\right)$ to examine photosynthesis and calcification responses. Overall, our study demonstrated that: (1) decreased calcification resulted in a down regulation of photoprotective mechanisms (i.e., as estimated via non-photochemical quenching, NPQ), pigments contents and photosynthetic carbon fixation; (2) calcification $(C)$ and photosynthesis $(P)$ (as well as their ratio) have different responses related to UVR with cells grown under the high $\mathrm{Ca}^{2+}$ concentration being more resistant to UVR than those grown under the low $\mathrm{Ca}^{2+}$ level; (3) elevated temperature increased photosynthesis and calcification of $E$. huxleyi grown at high $\mathrm{Ca}^{2+}$ concentrations whereas decreased both processes in low $\mathrm{Ca}^{2+}$ grown cells. Therefore, a decrease in calcification rates in E. huxleyi is expected to decrease photosynthesis rates, resulting in a negative feedback that further reduces calcification.
\end{abstract}

\section{Introduction}

Coccolithophores are organisms capable of fixing inorganic carbon into organic matter via photosynthesis as well as producing calcium carbonate crystals via intracellular calcifica- tion. In addition to their role as primary producers, coccolithophores play a predominant function in global ocean calcification (Rost and Riebesell, 2004), accounting for up to half of the share (Milliman, 1993). While still is under debate, calcification in coccolithophores appears to be strongly linked to photosynthesis by favoring supply of $\mathrm{CO}_{2}$ (Anning et al., 1996; Sikes et al., 1980; Sikes and Wilbur, 1982); moreover, Nimer et al. (1996) found reduced photosynthetic rates when removing external calcium. Other studies (Herfort et al., 2002, 2004; Trimborn et al., 2007; Leonardos et al., 2009) however, showed that changes in calcification under altered $\mathrm{Ca}^{2+}$ concentrations did not bring about concomitant changes in photosynthesis.

Calcification of coccolithophores is known to be influenced by many factors, such as light availability, nutrients, trace metals, $\mathrm{CO}_{2}$ as well as temperature (Paasche, 2002; Shiraiwa, 2003; Zondervan, 2007) and ultraviolet radiation (UVR, 280-400 nm) (Gao et al., 2009; Guan and Gao, 2010). Under a scenario of global climate change, important changes in the physiology of diverse aquatic organisms are expected (Beardall et al., 2009; Häder et al., 2011), especially due to variations in UVR and temperature levels. In this sense, it has been found that UVR strongly influences photosynthesis and calcification of Emiliania huxleyi under $\mathrm{CO}_{2}$-induced ocean acidification (Gao et al., 2009). In regard to the effects on coccolithophores of future ocean warming the results are rather varied: on the one hand, it was determined that photosynthesis could be promoted by increases in both $p \mathrm{CO}_{2}$ and temperature (Feng et al., 2008) but, on the other hand, De Bodt et al. (2010) suggested that ocean acidification had a larger adverse impact than surface water warming on coccolithophorids' calcification.

\section{Correspondence to: K. Gao}

(ksgao@xmu.edu.cn)

Published by Copernicus Publications on behalf of the European Geosciences Union. 
Emiliania huxleyi (Lohmann) W. W. Hay and H. P. Mohler is a cosmopolitan species that frequently form blooms in shallow-mixed surface oceanic waters with high light exposures (Nanninga and Tyrrell, 1996). This species is therefore of key ecological importance and constitutes an excellent model to evaluate physiological responses under variable environmental stressors as those occurring due to global change. In particular, it has been found that growth and photosynthesis of E. huxleyi are highly affected by UVR (Buma et al., 2000; Guan and Gao, 2010); furthermore, enhanced acidification of seawater exacerbated detrimental UVR effects on photosynthesis (Gao et al., 2009). In the present study, we further investigated if variations in calcification rates in $E$. huxleyi altered its photosynthetic responses to both UVR and temperature, in a context of global change. The experimental approach was to incubate low- and high $\mathrm{Ca}^{2+}$ acclimated E. huxleyi cells to different radiation conditions (using an artificial source) and temperatures treatments (20 and $25^{\circ} \mathrm{C}$ ) to determine the energy-dependant responses (i.e., biological weighting functions, BWFs) of both photosynthesis and calcification.

\section{Materials and methods}

\subsection{Organism and culture conditions}

A coccolith-bearing strain of Emiliania huxleyi (CS-369) was obtained from the Commonwealth Scientific and Industrial Research Organisation (CSIRO, Australia). The cells were grown in artificial seawater enriched with $100 \mu \mathrm{M}$ nitrate and $6.25 \mu \mathrm{M}$ phosphate and with trace metals and vitamins as specified for the Aquil medium (Price et al., 1988/89). Two calcium concentrations were used in our experiments - adjusted to $0.1 \mathrm{mM}$ (LCa) and $10 \mathrm{mM}(\mathrm{HCa})$ by adding $\mathrm{CaCl}_{2}$ - representing the reduced and ambient $\mathrm{Ca}^{2+}$ concentration of seawater, respectively. Ecologically, the reduced level of $\mathrm{Ca}^{2+}$ may be expected during coccolithophore blooms as observed in previous studies (Pitsyk, 1963; Cokacar et al., 2001; Mikaelyan et al., 2005) in estuarine systems where salinity was less than half the average oceanic value of $\sim 35$. Physiologically, reduced $\mathrm{Ca}^{2+}$ availability is an effective way to investigate the role of calcification (Brownlee et al., 1995). Semi-continuous cultures were maintained at $20^{\circ} \mathrm{C}$ at a PAR level of $150 \mu \mathrm{mol}$ photons $\mathrm{m}^{-2} \mathrm{~s}^{-1}$ (12 L:12 D). The media (i.e., $\mathrm{LCa}$ and $\mathrm{HCa}$ ) were renewed every 3 days, and cell concentrations were always kept $<10^{5}$ cells ml ${ }^{-1}$. The cells were grown for at least 100 days ( $>148$ generations) before being used in the experiments as described below.

\subsection{Experimentation}

Carbon incorporation and Pulse Amplitude Modulated (PAM) fluorescence measurements were done to assess the combined effects of ultraviolet radiation (UVR) and temperature on Emiliania huxleyi. Cells were exposed to artificial radiation under a solar simulator (Sol 1200W; A. G. Hönle, Martinsried, Germany) at a distance of $120 \mathrm{~cm}$ from the lamp for $2 \mathrm{~h}$. The irradiances output were measured with a broadband ELDONET filter radiometer (Real Time Computers, Möhrendorf, Germany) that has channels for PAR (400-700 nm), UV-A (315-400 nm) and UV$\mathrm{B}(280-315 \mathrm{~nm})$, and the measured values were $63.5 \mathrm{~W} \mathrm{~m}^{-2}$ $\left(290 \mu\right.$ mol photons $\left.\mathrm{m}^{-2} \mathrm{~s}^{-1}\right), 23.1 \mathrm{~W} \mathrm{~m}^{-2}$ and $1.20 \mathrm{~W} \mathrm{~m}^{-2}$, for PAR, UV-A and UV-B, respectively.

Biological weighting functions (BWFs) were used to separate the effects of different UV wavebands on photosynthesis, calcification, effective photochemical quantum yield of PSII $(Y)$ and non-photochemical quenching (NPQ). Six different radiation treatments were set by using Schott cut-off filters that cut radiation below 280, 295, 305, 320, 350 and $395 \mathrm{~nm}$ (the transmission spectra of these filters are published elsewhere, Villafañe et al., 2003). For each experimental $\mathrm{Ca}^{2+}$ concentration, the samples were dispensed in six quartz tubes $(14 \mathrm{ml})$ per radiation treatment (i.e., under each Schott filter). Thus a total of 36 tubes were irradiated; half of them were used for measurements of photosynthetic carbon fixation and calcification whereas the other half was used for PAM measurements (see below). The tubes containing the samples were put in a water bath for temperature control at $20^{\circ} \mathrm{C}$ or $25^{\circ} \mathrm{C}$ using a circulating cooler (CTP-3000, Eyela, Tokyo, Japan). Due to the effective irradiance area under the solar simulator, it was not possible to test the effects of both temperatures at the same time, so experiments were done one after the other. In this way we were sure that the irradiance received by the cells were the same.

\subsection{Analyses and measurements}

The $\mathrm{pH}$ was measured with a potentiometric titrator (DL15, Mettler-Toledo, Schwerzenbach, Switzerland) which was calibrated against Standard National Bureau of Standards (NBS) buffer solution (Hanna). The alkalinity of the media was also measured with the potentiometric titrator. The carbonate system was calculated from temperature, salinity, $\mathrm{pH}$ and concentrations of total alkalinity and phosphate, using the program $\mathrm{CO}_{2}$ sys (Lewis and Wallace, 1998). Equilibrium constants of Mehrbach et al. (1973) modified by Dickson and Millero (1987) were chosen for the calculations.

Just before experimentation, samples were taken for determination of pigments and quantification of cells. Cell densities were determined using a Coulter counter (Z2, Beckman Instruments, Florida, US) and specific growth rate was calculated as:

$\mu=\left(\ln N_{t}-\ln N_{0}\right) / \Delta t$

where $N_{0}$ and $N_{t}$ are the cell concentrations after and before renewing the medium.

For pigments determination, $100 \mathrm{ml}$ of sample was filtered onto Whatman GF/F filters $(25 \mathrm{~mm})$ under low pressure $(200 \mathrm{mbar})$ and extracted overnight either in absolute 
methanol (for chlorophyll- $a$ (chl- $a$ ) determinations) or $90 \%$ acetone (for carotenoids content) at $4{ }^{\circ} \mathrm{C}$. After extraction and centrifugation $(10 \mathrm{~min}$ at $5000 \times \mathrm{g})$ the absorbance of the supernatant was determined with a scanning spectrophotometer (DU800, Beckman, Fullerton, California, USA). The chl- $a$ content was calculated according to Porra (2002) whereas that of carotenoids using the equations of Strickland and Parsons (1972). In addition, an aliquot of $10 \mathrm{ml}$ of culture (both from the $\mathrm{HCa}$ and $\mathrm{LCa}$ treatments) was filtered very gently onto $0.22 \mu \mathrm{m}$ MCE (Mixed Cellulose Ester) filters (Xinya Instrument Co., Shanghai, China), washed three times with $0.2 \mathrm{M}$ phosphate buffer $(\mathrm{pH}=8)$ and then dried at $45^{\circ} \mathrm{C}$. The filters were coated with gold and then examined with a scanning electron microscope (Field Emission SEM, LEO 1530, Germany).

Fluorescence measurements were performed at 40, 80 and $120 \mathrm{~min}$ since the beginning of the incubations. Fluorescence parameters were determined with a pulse amplitude modulated fluorometer (model Xe-PAM, Walz, Effeltrich, Germany). The effective photochemical quantum yield of PSII $(Y)$ was determined by measuring the instant maximal fluorescence $\left(F_{m}^{\prime}\right)$ and the steady state fluorescence $\left(F_{t}\right)$ of light adapted cells using a saturating white light pulse ( $5000 \mu \mathrm{mol}$ photons $\mathrm{m}^{-2} \mathrm{~s}^{-1}$ in $0.8 \mathrm{~s}$ ) in the presence of a weak measuring light $\left(0.3 \mu \mathrm{mol}\right.$ photons $\left.\mathrm{m}^{-2} \mathrm{~s}^{-1}\right)$ and actinic light $\left(300 \mu \mathrm{mol}\right.$ photons $\mathrm{m}^{-2} \mathrm{~s}^{-1}$, i.e., similar PAR level as under the radiation treatments). $Y$ was estimated according to Genty et al. (1989) as:

$Y=\left(F_{m}^{\prime}-F_{t}\right) / F_{m}^{\prime}$

UVR-induced inhibition of $Y$ was calculated as:

$\operatorname{Inh}(\%)=\left(Y_{395}-Y_{320 / 280}\right) \cdot Y_{395}^{-1} \cdot 100$

where $Y_{395}$ represents the $Y$ under the PAR $(395-700 \mathrm{~nm})$ treatment, while $Y_{320 / 280}$ represents the $Y$ under the PA $(320-700 \mathrm{~nm})$ or PAB $(280-700 \mathrm{~nm})$ treatments, respectively. Non-photochemical quenching (NPQ) was calculated as:

$\mathrm{NPQ}=\left(F_{m}-F_{m}^{\prime}\right) / F_{m}^{\prime}$

where the $F_{m}$ represents the maximum fluorescence yield after 10 min of dark adaptation.

For measurements of photosynthesis and calcification, samples (i.e., from the $\mathrm{HCa}$ and $\mathrm{LCa}$ treatments) were dispensed into $14 \mathrm{ml}$ quartz tubes and inoculated with $100 \mu \mathrm{l}-10 \mu \mathrm{Ci}\left(0.37 \mathrm{MBq}\right.$ ) of $\mathrm{NaH}^{14} \mathrm{CO}_{3}$ (ICN Radiochemicals, Irvine, California, USA). After incubating for $2 \mathrm{~h}$, subsamples for total $(5 \mathrm{ml})$ and organic $(5 \mathrm{ml})$ carbon were collected onto Whatman GF/F glass fiber filters $(25 \mathrm{~mm})$ under low pressure (200 mbar), rinsed three times with the medium and put in $20 \mathrm{ml}$ scintillation vials. For the determination of organic carbon, the filters were exposed to $\mathrm{HCl}$ fumes overnight and dried at $45^{\circ} \mathrm{C}$; then they were digested in scintillation cocktail (Hisafe 3, Perkin-Elmer, Shelton, CT, USA) and the activity of the fixed radiocarbon counted with a scintillation counter (Tri-Carb 2800TR, Perkin-Elmer, Shelton, CT, USA). The calcification rate was calculated as the difference between total (non acidified filters) and organic particulate carbon fixation (acidified filters) as previously reported (Gao et al., 2009; Guan and Gao, 2010).

Biological weighting functions (BWFs) for inhibition of $Y$, NPQ, photosynthetic carbon fixation and calcification were calculated using an exposure-response curve based on irradiance (Neale and Kieber, 2000). The biological responses for each wavelength interval over the incubation period were expressed as a function of the average irradiance (over incubation time) in the exposure wavelength interval. The relative spectral emission of the solar simulator was determined using a USB diode array spectroradiometer (HR 2000CG-UV-NIR, Ocean Optics, Duneclin, USA). An exponential decay function (base 10) was used to fit the data in each experiment, and the exponent of the function was expressed as a two-degree polynomial function; the best fit was then obtained by iteration $\left(r^{2}>0.95\right)$.

Data were analyzed using the SPSS v.16.0 software. Interactive effects among $\mathrm{Ca}^{2+}$ concentration, temperature, radiation treatments and exposure time on $Y, \mathrm{NPQ}$, photosynthetic carbon fixation $(P)$, calcification rate $(C)$ and $C / P$ were statistically analyzed using a two, three or four-way ANOVA test to establish significance $(p<0.05)$ among the variables. The Student Newman-Keuls (SNK) test with a level of significance set at $p<0.05$ was used for post-hoc comparisons. The Student's t-test was also used to analyze growth rates and pigments data.

\section{Results}

\subsection{Carbonate chemistry, growth rates, pigments and morphology}

The parameters for the carbonate system of the media are presented in Table 1 . Total alkalinity (TA) and $\mathrm{CO}_{3}^{2-}$ concentration were significantly different, with higher TA and $\mathrm{CO}_{3}^{2-}$ levels in the $\mathrm{HCa}$ medium. All other parameters did not show significant differences between the two media. After 3 days of culturing and prior to the renewal of media, the $\mathrm{pH}$ in both treatments increased to $<0.07$; the other parameters did not show significant differences among the two $\mathrm{Ca}^{2+}$ treatments.

During the acclimation period, reduced $\mathrm{Ca}^{2+}$ concentration did not significantly affect growth rates, but it significantly decreased $(p<0.05)$ the chl- $a$ and carotenoids contents by $26.7 \%$ and $20 \%$, respectively (Table 2 ). The SEM images showed no coccolith-covered surface in cells grown at LCa, and furthermore, the coccoliths were partially dissolved and malformed (Fig. 1a). Instead, cells grown at $\mathrm{HCa}$ showed entire and strongly calcified coccoliths (Fig. 1b). 
Table 1. Parameters of the artificial seawater carbonate system at the ambient $(10 \mathrm{mM})$ and reduced $(0.1 \mathrm{mM})$ levels of $\mathrm{Ca}^{2+}$ equilibrated with ambient $\mathrm{CO}_{2}(39.3 \mathrm{~Pa})$. Total alkalinity, $\mathrm{pH}$, salinity, nutrient concentration and temperature were used to derive all other parameters using a $\mathrm{CO}_{2}$ system analyzing software $\left(\mathrm{CO}_{2}\right.$ sys). Data are the means $\pm \mathrm{SD}$ of 3 measurements. The asterisks denote significant difference between the two $\mathrm{Ca}^{2+}$ concentrations.

\begin{tabular}{llllllll}
\hline $\begin{array}{l}\mathrm{Ca}^{2+} \\
(\mathrm{mM})\end{array}$ & $\mathrm{pH}_{\mathrm{NBS}}$ & $\begin{array}{l}\mathrm{TA} \\
\left(\mu \mathrm{mol} \mathrm{kg}{ }^{-1}\right)\end{array}$ & $\begin{array}{l}p \mathrm{CO}_{2} \\
(\mathrm{ppmV})\end{array}$ & $\begin{array}{l}\mathrm{DIC} \\
\left(\mu \mathrm{mol} \mathrm{kg}{ }^{-1}\right)\end{array}$ & $\begin{array}{l}\mathrm{CO}_{2} \\
\left.(\mu \mathrm{mol} \mathrm{kg})^{-1}\right)\end{array}$ & $\begin{array}{l}\mathrm{HCO}_{3}^{-} \\
\left(\mu \mathrm{mol} \mathrm{kg}^{-1}\right)\end{array}$ & $\begin{array}{l}\mathrm{CO}_{3}^{2-} \\
\left.(\mu \mathrm{mol} \mathrm{kg})^{-1}\right)\end{array}$ \\
\hline 10 & $8.20 \pm 0.01$ & $2539 \pm 12^{*}$ & $405 \pm 6$ & $2238 \pm 11$ & $13 \pm 0.2$ & $2008 \pm 10$ & $216 \pm 3^{*}$ \\
0.1 & $8.20 \pm 0.01$ & $2496 \pm 24^{*}$ & $405 \pm 15$ & $2202 \pm 28$ & $13 \pm 0.5$ & $1979 \pm 29$ & $210 \pm 2^{*}$ \\
\hline
\end{tabular}

Table 2. Growth rate (in $\mathrm{d}^{-1}$ ), chl- $a$ and carotenoid content (in pg cell ${ }^{-1}$ ) of Emiliania huxleyi cells acclimated to $10 \mathrm{mM}$ ( $\mathrm{HCa}$ ) or $0.1 \mathrm{mMCa}^{2+}(\mathrm{LCa})$ for at least 148 generations. $N$ represents the number of samples. The asterisks represent significant differences between two $\mathrm{Ca}^{2+}$ concentrations.

\begin{tabular}{|c|c|c|c|}
\hline \multirow[t]{2}{*}{ Variable } & \multicolumn{2}{|c|}{$\mathrm{Ca}^{2+}(\mathrm{mM})$} & \multirow[t]{2}{*}{$p$} \\
\hline & 10 & 0.1 & \\
\hline Specific growth rate $\left(\mathrm{d}^{-1}\right)$ & $1.07 \pm 0.04(n=14)$ & $1.03 \pm 0.05(n=10)$ & $p>0.05$ \\
\hline Chl- $a\left(\mathrm{pg} \mathrm{cell}^{-1}\right)$ & $0.15 \pm 0.01(n=6)^{*}$ & $0.11 \pm 0.01(n=6)$ & $p<0.001$ \\
\hline Carotenoids (pg cell ${ }^{-1}$ ) & $0.30 \pm 0.02(n=6)^{*}$ & $0.24 \pm 0.02(n=6)$ & $p<0.01$ \\
\hline
\end{tabular}

\subsection{Chl- $a$ fluorescence parameters}

The main feature of chl- $a$ fluorescence parameters was of $Y$ being significantly lower $(p<0.05)$ when samples were exposed to shorter UVR wavebands - i.e., the lowest $Y$ was determined in the $280-700 \mathrm{~nm}$ range whereas the highest was in the $400-700 \mathrm{~nm}$ (Fig. 2). Additionally, at $20^{\circ} \mathrm{C}$, significantly higher $(p<0.05) Y$ values were determined in the $\mathrm{HCa}$ as compared to the $\mathrm{LCa}$ treatment. Furthermore, at $20^{\circ} \mathrm{C}$, the $Y$ differences among $\mathrm{Ca}^{2+}$ treatments decreased significantly $(p<0.05)$ as the experiment progressed (i.e., at different times of exposure to radiation). After 40 (Fig. 2a) and $80 \mathrm{~min}$ (Fig. 2b) of exposure under the solar simulator, $Y$ values at all radiation treatments were significantly higher $(p<0.05)$ in the HCa than in the LCa treatment. However, there were no significant differences $(p=0.06)$ after $2 \mathrm{~h}$ (Fig. 2c) of exposure to radiation. There was a significant effect of temperature (as seen in the ratio of $Y$ at the two tested temperatures) with samples in the LCa treatments having significantly higher $(p<0.05) Y$ values at $25^{\circ} \mathrm{C}$ than at $20^{\circ} \mathrm{C}$ when incubated during 40 (Fig. 2a) and $80 \mathrm{~min}$ (Fig. 2b), while there were no differences after $2 \mathrm{~h}$ of incubation (Fig. 2c). In contrast, samples in the $\mathrm{HCa}$ treatment had always significantly higher $(p<0.05) Y$ values at $20^{\circ} \mathrm{C}$ as compared to those at $25^{\circ} \mathrm{C}$, resulting in $Y_{25 / 20}$ ratio $<1$ at all incubation times.

The inhibition of $Y$ due to UVA, UVB and UVR at different incubation times is shown in Fig. 3. In general, the $Y$ inhibition increased with increasing exposure time to UVR wavebands. HCa had significantly but slightly lower inhibition $(p<0.05)$ than LCa treatments at $40 \mathrm{~min}$ and $80 \mathrm{~min}$, but there were no significant differences between the two $\mathrm{Ca}^{2+}$ concentrations after $2 \mathrm{~h}$. However, inhibition of $Y$ due to UVA (Fig. 3a) decreased slightly but significantly with time $(p<0.001)$, whereas that due to UVB slightly increased $(p<0.001)$. For UVA-induced inhibition (Fig. 3a) values of $\sim 21-34 \%$ were determined after $40 \mathrm{~min}$ of exposure whereas they were slightly lower after $80 \mathrm{~min}(\sim 13$ $20 \%)$ and $2 \mathrm{~h}(\sim 10-16 \%)$. UVB-induced inhibition of $Y$ was higher (i.e., $>40 \%$ ) than that due to UVA and increased with exposure time from values of $\sim 41-50 \%$ at $40 \mathrm{~min}$ to $\sim 55-60 \%$ after $2 \mathrm{~h}$ of exposure (Fig. 3b). The UVR-induced inhibition of $Y$ (Fig. 3c) varied from $\sim 71-77 \%$ and $\sim 62-$ $74 \%$ for $\mathrm{LCa}$ and $\mathrm{HCa}$, respectively.

Figure 4 shows the responses of one photoprotective mechanism, as assessed through thermal dissipation of excess energy (i.e., non-photochemical quenching, NPQ). The general pattern was of higher NPQ values $(p<0.05)$ with increasing exposure to UVR wavebands, so that those samples receiving UVR wavelengths had higher NPQ than those receiving only PAR. Additionally, for any radiation treatment, there was a trend for higher NPQ values $(p<0.05)$ at high temperatures, which was especially evident in incubations lasting $80 \mathrm{~min}$ (Fig. 4b). Another interesting feature was of higher NPQ values $(p<0.05)$ in $\mathrm{HCa}$ than in $\mathrm{LCa}$ cells for any radiation treatment at $20^{\circ} \mathrm{C}$; again, this trend was more evident during short time exposures (Fig. 4a) than at the end of the incubation (i.e., after $2 \mathrm{~h}$, Fig. $4 \mathrm{c}$ ). With 


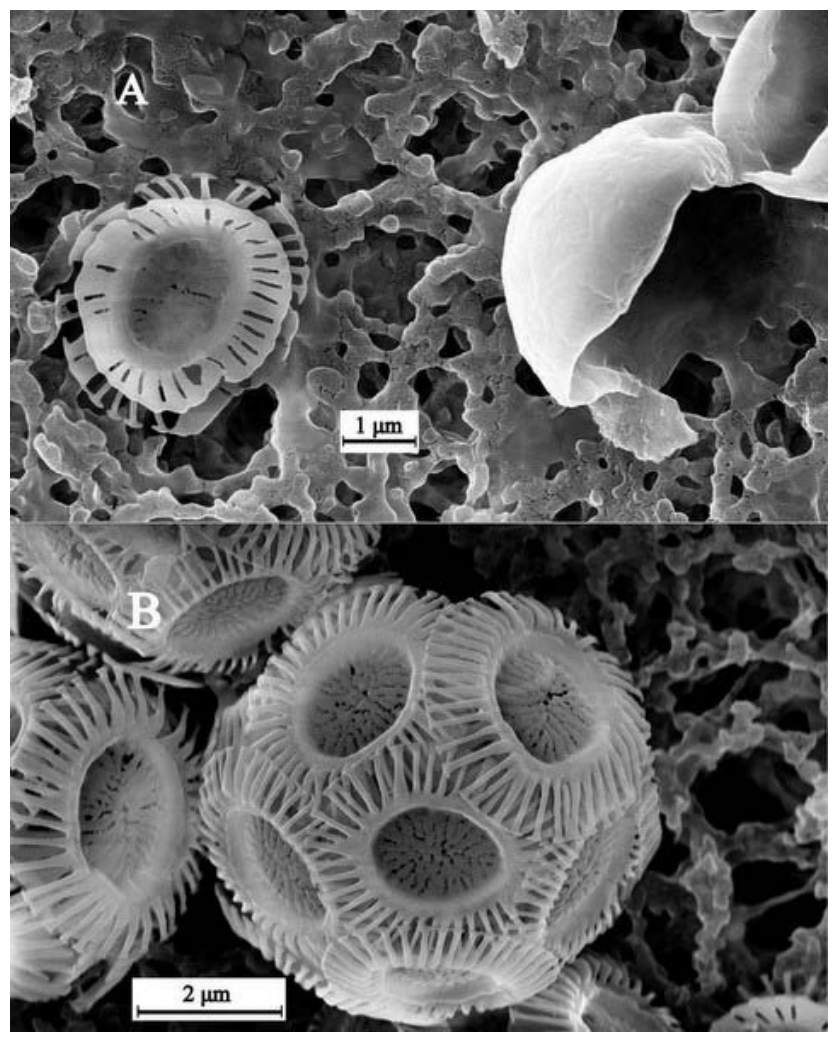

Fig. 1. Scanning electron microscope images of Emiliania huxleyi cells grown at: (A) $0.1 \mathrm{mMCa}^{2+}$ and, (B) $10 \mathrm{mMCa}^{2+}$ grown at $20^{\circ} \mathrm{C}$ and under PAR illumination of $150 \mu \mathrm{mol} \mathrm{m}^{-2} \mathrm{~s}^{-1}$.

increasing exposure time, NPQ at $25^{\circ} \mathrm{C}$ of $\mathrm{HCa}$ cells decreased $(p<0.05)$ whereas in LCa increased $(p<0.05)$, so that NPQ differences between the two temperature levels decreased in the HCa-grown cells and increased in the LCa-grown ones, respectively. After $2 \mathrm{~h}$, there was no significant difference between the two $\mathrm{Ca}^{2+}$ concentrations at $20^{\circ} \mathrm{C}(p>0.05$, Fig. $4 c)$.

\subsection{Photosynthetic carbon fixation $(P)$, calcification rates $(C)$ and $C / P$}

Photosynthetic carbon fixation of Emiliania huxleyi (Fig. 5a) was stimulated by eliminating the shorter wavelengths of the spectrum. The general pattern was of higher photosynthetic carbon values $(p<0.05)$ in the HCa-grown than in the LCa-grown cells. The beneficial effect of temperature was clearly evident in samples acclimated to $\mathrm{HCa}$ (Fig. 5a) so that, for example, the highest photosynthetic carbon at $25^{\circ} \mathrm{C}$ (Fig. 5a) was $0.76 \mathrm{pg} \mathrm{C}$ cell $^{-1} \mathrm{~h}^{-1}$ whereas at $20^{\circ} \mathrm{C}$ was $0.58 \mathrm{pg} \mathrm{C}$ cell $^{-1} \mathrm{~h}^{-1}$. Under PAR alone (i.e., $>395 \mathrm{~nm}$ treatment), however, high temperature significantly inhibited photosynthesis $(p<0.05)$ by $10.1 \%$ in the LCa-grown cells. Under UVR, high temperature did not show significant effects on carbon incorporation in the LCa-grown cells.
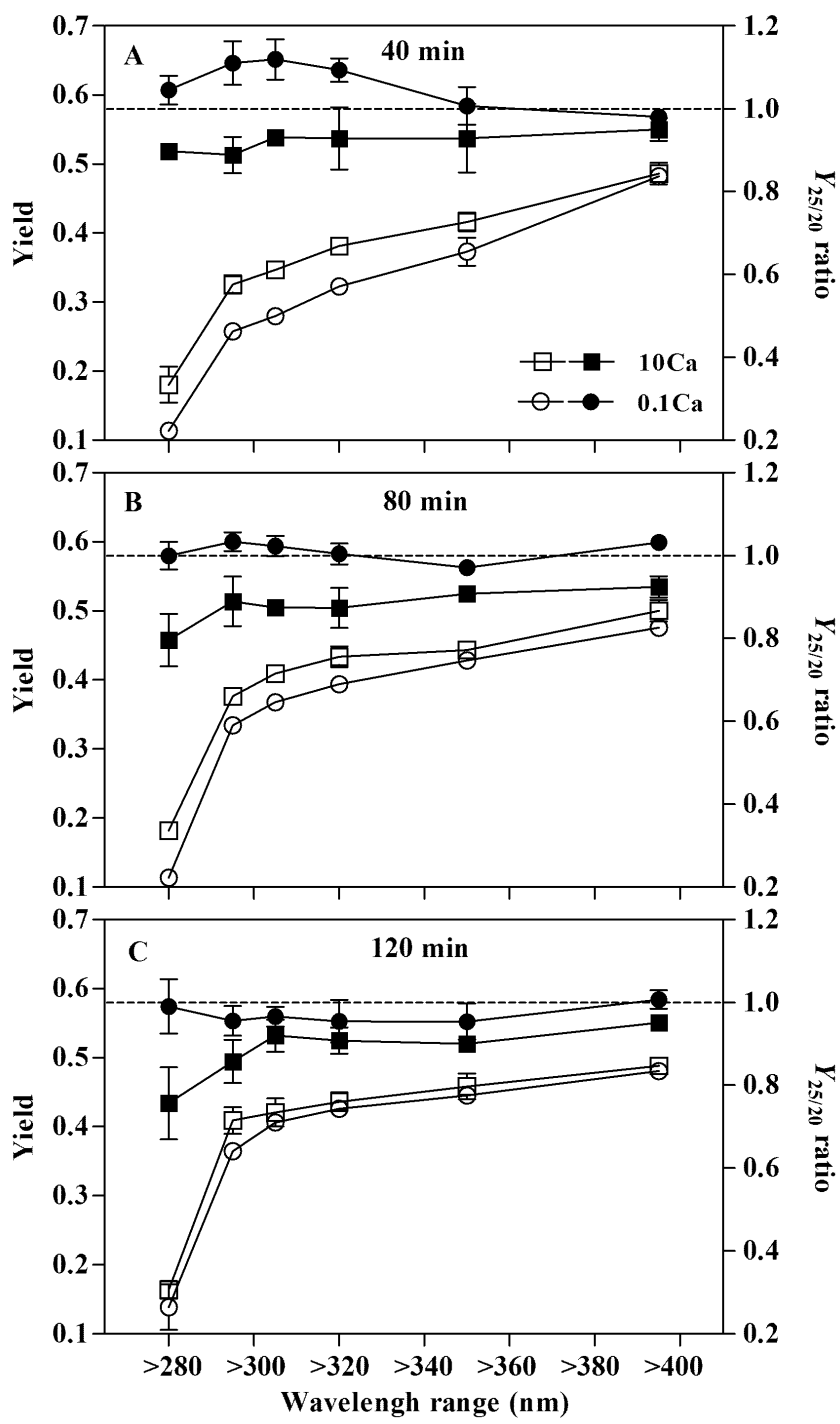

Fig. 2. Effective photochemical quantum yield $\left(F_{v}^{\prime} / F_{m}^{\prime}\right)$ of Emiliania huxleyi cells grown at $\mathrm{HCa}$ (squares) and LCa (circles). Open symbols indicate $F_{v}^{\prime} / F_{m}^{\prime}$ measured at $20^{\circ} \mathrm{C}$ whereas black symbols indicate the ratio of $F_{v}^{\prime} / F_{m}^{\prime}$ measured at $25^{\circ} \mathrm{C}$ to that at $20^{\circ} \mathrm{C}$. Measurements done after exposures to artificial radiation: (A) $40 \mathrm{~min}$, (B) $80 \mathrm{~min}$ and, (C) $120 \mathrm{~min}$. The bars on top of the symbols represent the standard deviation $(n=3)$.

Similar responses were determined in regard to calcification rates (Fig. 5b) with the highest values determined under PAR alone, further benefited by high temperatures especially in the $\mathrm{HCa}$-grown cells, in which calcification rates increased from 0.21 to $0.30 \mathrm{pg} \mathrm{C} c e l l^{-1} \mathrm{~h}^{-1}$ at 20 and $25^{\circ} \mathrm{C}$, respectively. Calcification rates of $\mathrm{LCa}$ were low for all radiation and temperatures treatments. The calcification to photosynthesis ratio $(C / P)$ of the HCa-grown cells increased slightly with increasing wavelength (Fig. 5c) but there was no clear effect of temperature at both $\mathrm{Ca}^{2+}$ concentrations. 


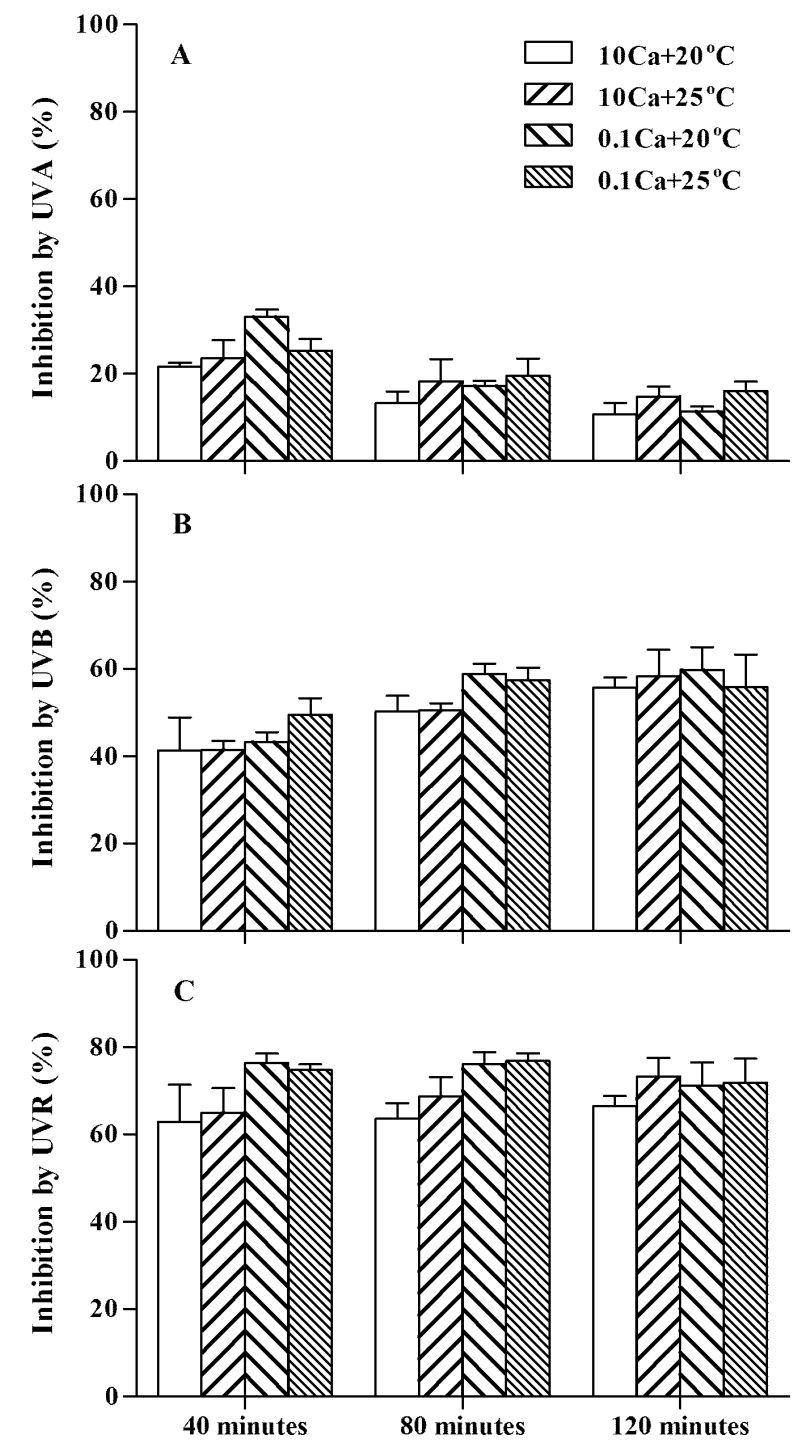

Fig. 3. Inhibition of the effective photochemical quantum yield of Emiliania huxleyi cells due to: (A) UVA, (B) UVB and, (C) UVR after 40,80 and $120 \mathrm{~min}$ of exposure to artificial radiation. The lines on top of the bars represent the standard deviations $(n=3)$.

Figure 6 shows the relative contribution of UVA and UVB in causing inhibition of photosynthesis, calcification and $C / P$. For photosynthesis and calcification, higher inhibition $(p<0.05)$ by UVB as compared to that of UVA was determined. For both $\mathrm{Ca}^{2+}$ treatments, however, temperature did not show significant effects on inhibition of photosynthetic carbon fixation and calcification rates $(p>0.05$, Fig. 6a and b). Finally, UVA induced inhibition of $C / P$ showed significant $(p<0.05)$ differences among the two $\mathrm{Ca}^{2+}$ concentrations (Fig. 6c), but it did not among temperatures. Shorter wavelengths of UVB showed opposite responses: UVB-induced inhibition of $C / P$ was significantly different among the two $\mathrm{Ca}$ concentrations, being positive for

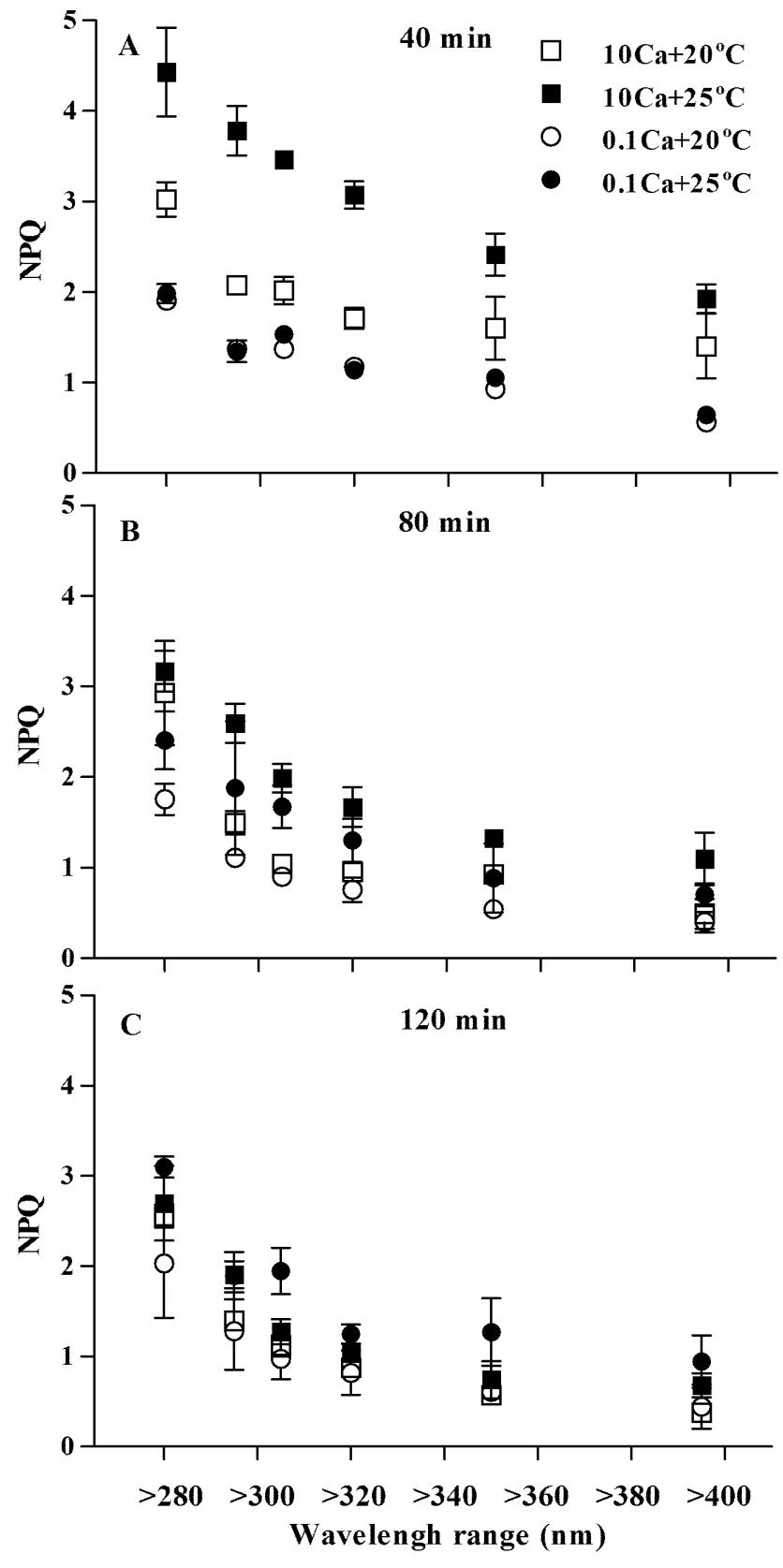

Fig. 4. Non photochemical quenching (NPQ) of Emiliania huxleyi cells grown at $\mathrm{HCa}$ (squares) and LCa (circles) and exposed to different radiation and temperature treatments. Open and filled symbols are cells exposed at $20^{\circ} \mathrm{C}$ and $25^{\circ} \mathrm{C}$, respectively. Measurements done after exposures to artificial radiation: (A) $40 \mathrm{~min}$, (B) $80 \mathrm{~min}$ and, (C) $120 \mathrm{~min}$. The bars on top of the symbols represent the standard deviation $(n=3)$.

the HCa-grown and negative for the LCa-grown cells, respectively (Fig. 6c). Furthermore, high temperature significantly reduced inhibition of $C / P$ due to UVB ( $p<0.001$, Fig. $6 c)$. 

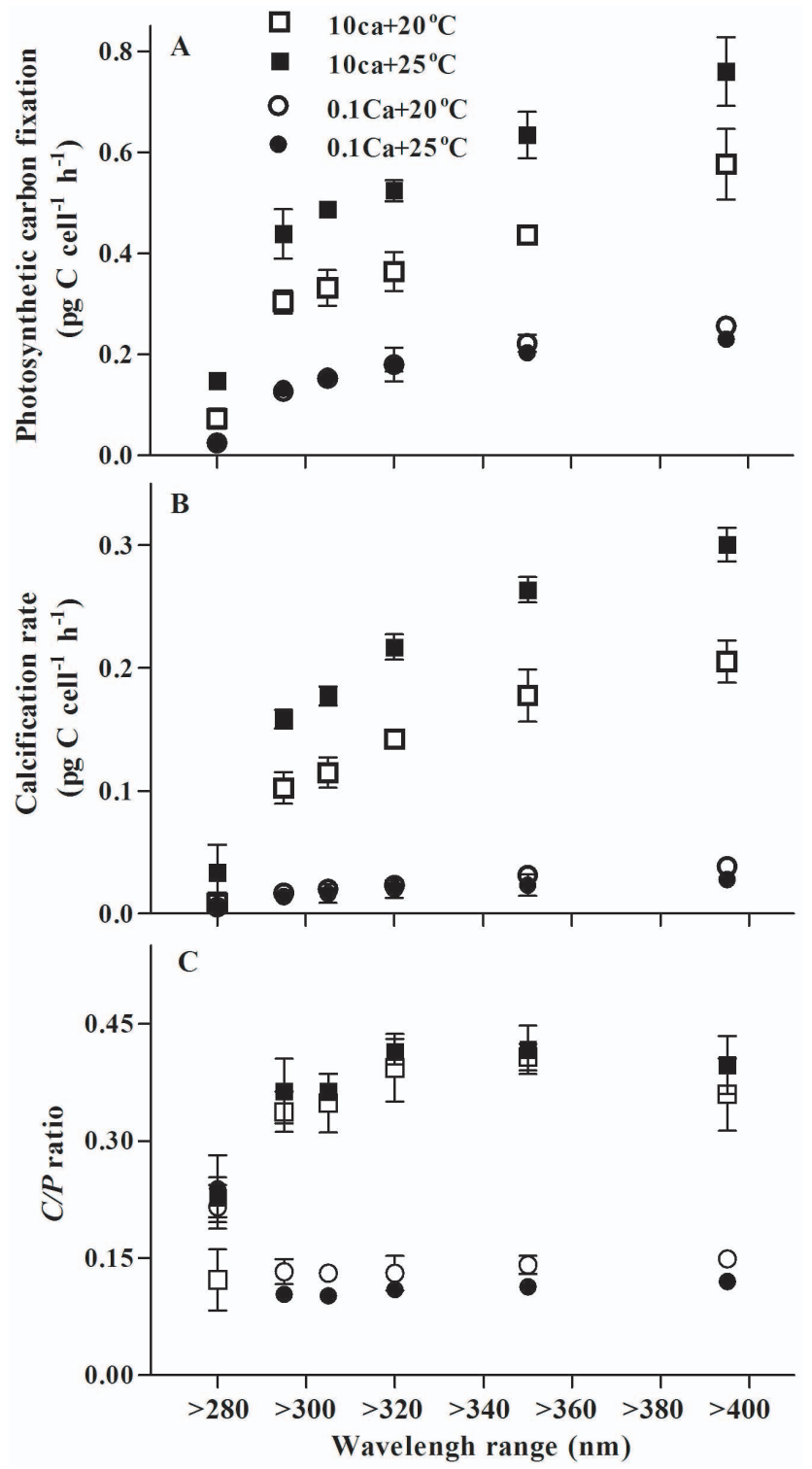

Fig. 5. (A) Photosynthetic carbon fixation (in $\mathrm{pg} \mathrm{C} \mathrm{Cell}^{-1} \mathrm{~h}^{-1}$ ), (B) Calcification rate (in $\mathrm{pgCcell}{ }^{-1} \mathrm{~h}^{-1}$ ) and, (C) $C / P$ ratio of Emiliania huxleyi cells grown at $\mathrm{HCa}$ (squares) and $\mathrm{LCa}$ (circles) and exposed to different radiation and temperature treatments for $2 \mathrm{~h}$. Open and filled symbols are cells exposed at $20^{\circ} \mathrm{C}$ and $25^{\circ} \mathrm{C}$, respectively. The bars on top of the symbols represent the standard deviation $(n=3)$.

\subsection{BWF}

There were similar trends of BWFs for inhibition of $Y$ (Fig. 7a), photosynthetic carbon fixation (Fig. 7c) and calcification (Fig. 7d) with decreasing weights towards higher wavelengths. On the other hand, BWFs for inhibition of NPQ (Fig. 7b) showed an opposite response i.e., NPQ was promoted by exposure to short wavelengths. In general, all BWFs did not exhibit significant differences among the two $\mathrm{Ca}$ concentrations and the two temperatures tested.

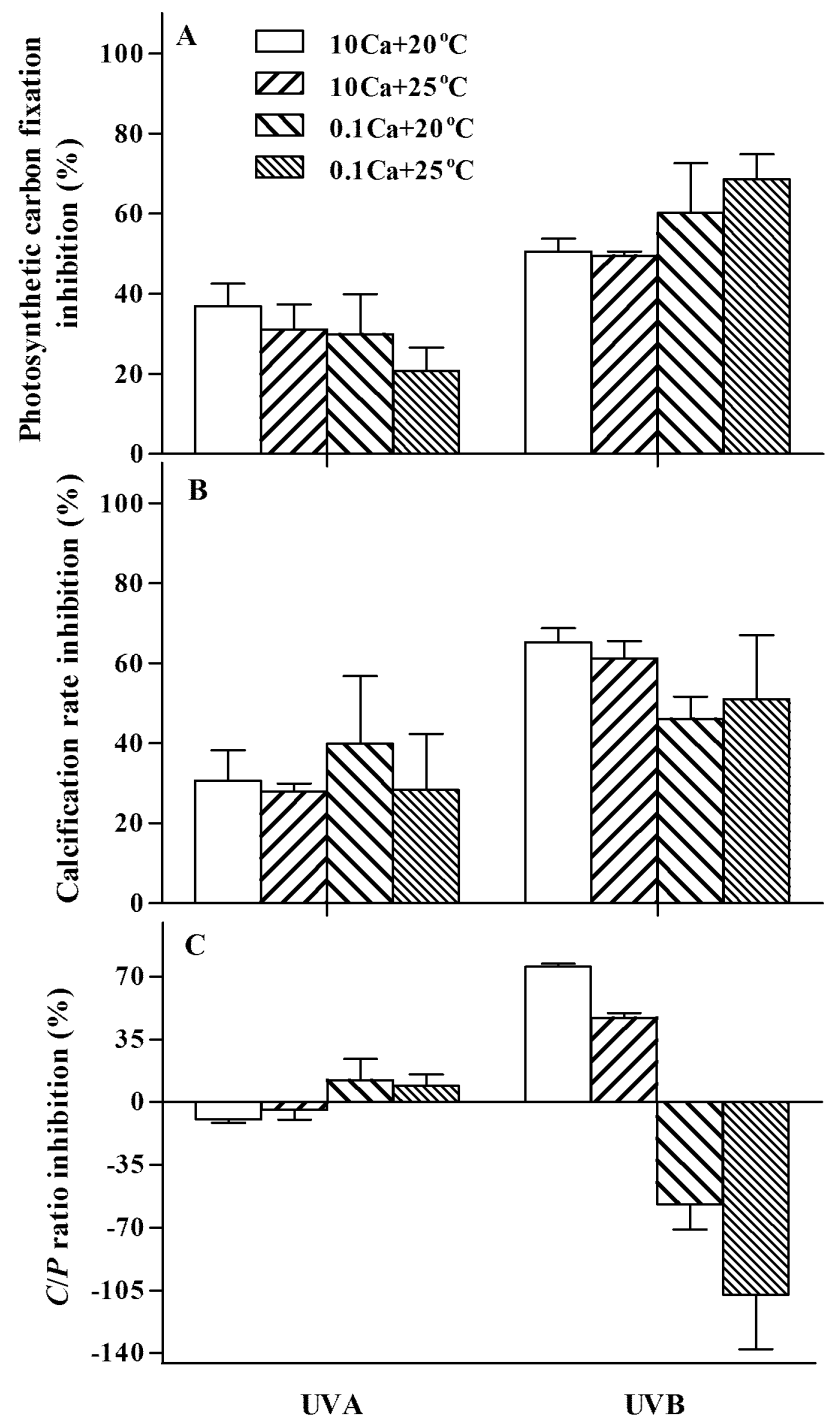

Fig. 6. UVR-induced inhibition of (A) Photosynthetic carbon fixation, (B) Calcification rate and, (C) $C / P$ ratio of Emiliania huxleyi cells. The lines on top of the bars represent the standard deviations $(n=3)$.

\section{Discussion}

The results of our study can be summarized as follows: (1) decreased calcification resulted in a decrease of photoprotective mechanisms (NPQ), pigments contents and photosynthetic carbon fixation; (2) calcification and photosynthesis (and their ratio) showed different responses related to UVR, with the HCa-grown cells having more tolerance to UVR than the LCa-grown ones; (3) elevated temperature increased photosynthesis and calcification of Emiliania huxleyi, grown at high $\mathrm{Ca}^{2+}$ concentrations whereas the opposite was observed in low $\mathrm{Ca}^{2+}$ grown cells. In the following paragraphs we will discuss the possible causes of the differential responses observed in our study. 

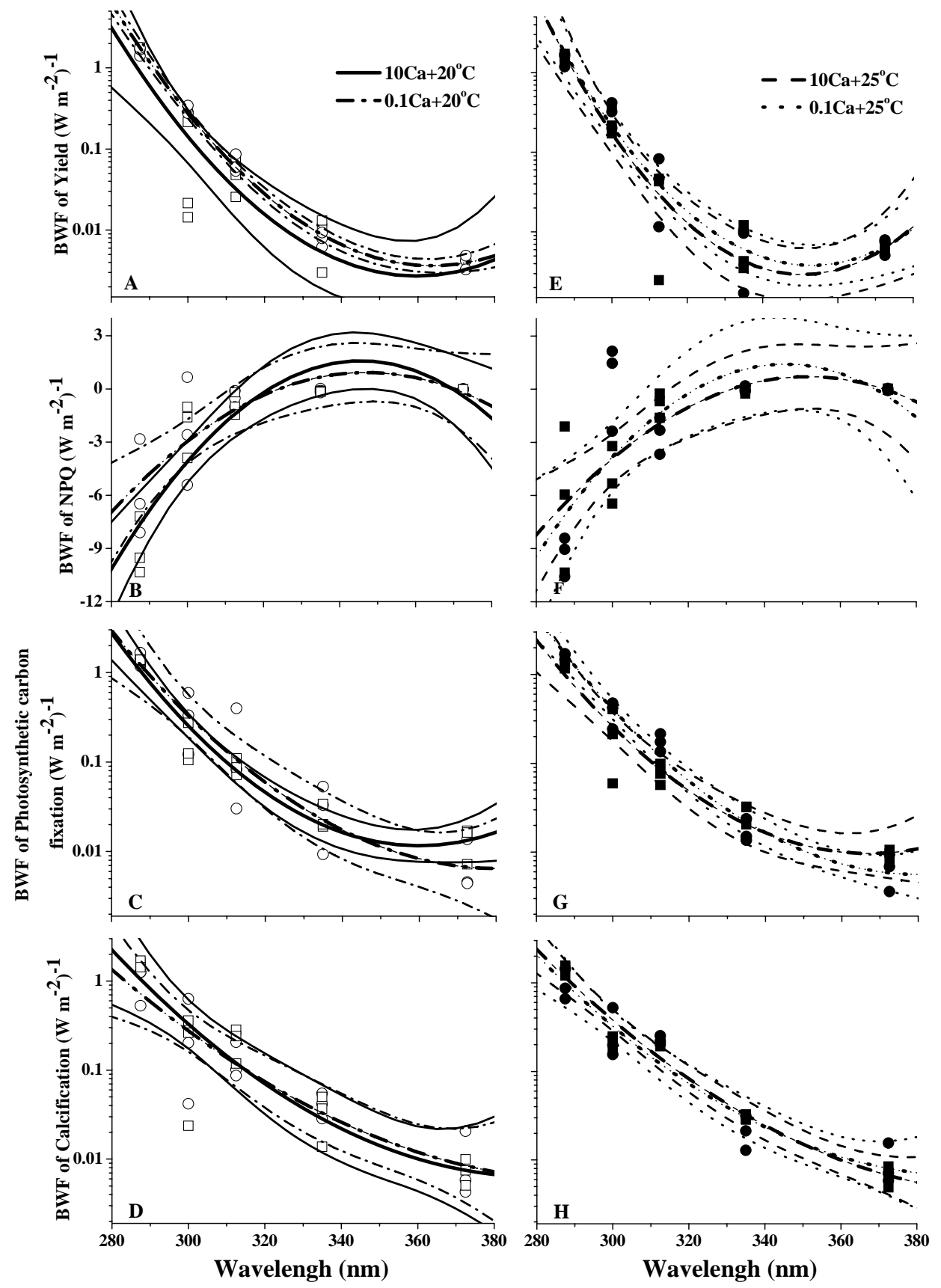

Fig. 7. Biological weighting functions (BWFs, in $\left(\mathrm{W} \mathrm{m}^{-2}\right)^{-1}$ ) of Emiliania huxleyi: (A and E) effective photochemical quantum yield $(Y)$; (B and F) non photochemical quenching (NPQ); (C and G) photosynthetic carbon fixation and, $(\mathbf{D}$ and $\mathbf{H})$ calcification rate of cells grown at $\mathrm{HCa}$ and $\mathrm{LCa}$ concentrations. The symbols represent the different combinations of $\mathrm{Ca}^{2+}$ concentration and temperature: open squares: $\mathrm{HCa}$ cells at $20^{\circ} \mathrm{C}$; filled squares: $\mathrm{HCa}$ cells at $25^{\circ} \mathrm{C}$; open circles: LCa cells at $20^{\circ} \mathrm{C}$ and filled circles: LCa cells at $25^{\circ} \mathrm{C}$.

Emiliania huxleyi depends on $\mathrm{Ca}^{2+}$ to form carbonate crystals that build up the coccolith shell that shelters the cells. $\mathrm{Ca}^{2+}$ availability is also associated to other process, as seen in other studies (Trimborn et al., 2007; Leonardos et al., 2009) that demonstrated that cells grown under low $\left(0.1 \mathrm{mM} \mathrm{Ca}^{2+}\right)$ or without $\mathrm{Ca}^{2+}$ decreased their growth rates as compared to those cultured under higher $\mathrm{Ca}^{2+}$ concentrations (e.g., 1-10 mM). Similarly, in our study we determined a significant decrease in the growth rates of $E$. huxleyi cells after being transferred from $10 \mathrm{mMCa}^{2+}$ to $0.1 \mathrm{mMCa}^{2+}$, but only during the initial 12 generations in 9 days (data not shown). After 100 days (148 generations), there were no 
significant differences in growth rates between the two $\mathrm{Ca}^{2+}$ concentrations (Table 2), clearly suggesting that acclimation to the lowered $\mathrm{Ca}^{2+}$ level took longer time than expected (Herfort et al., 2002, 2004; Trimborn et al., 2007; Leonardos et al., 2009). Nevertheless, significant differences between the two $\mathrm{Ca}^{2+}$ concentrations were observed in the amount of pigments - chl- $a$ and carotenoids per cell (Table 2). The increased contents of the photosynthetic pigments are probably due to the reduced radiation levels received by $\mathrm{HCa}$ grown cells, which had coccolith shelter. In fact, it was previously shown that the coccolith layer reduces the transmission of both UV and PAR, i.e., over $15 \%$ of PAR was absorbed by the coccolith layer compared to naked cells (Gao et al., 2009); therefore, LCa-grown cells with less or without coccoliths received relatively more radiation. Consequently, after long-term acclimation to less radiation the $\mathrm{HCa}$-grown cells upregulated their contents of chl- $a$, with an increase of the antenna size, reflecting a classical shade adaptation behavior.

The E. huxleyi cells grown at the high $\mathrm{Ca}^{2+}$ concentration had higher photosynthetic carbon fixation, calcification rate and more tolerance to UVR than those grown at low $\mathrm{Ca}^{2+}$ concentration. In addition, under UVR exposure, elevated temperature enhanced photosynthesis of the $\mathrm{HCa}$ grown cells as compared to the LCa-grown ones (Figs. 2 and 5). There are several mechanisms that might account for part of the observed variations in the responses. For example, dissipation of excess energy as heat (NPQ) is a well known photoprotective mechanism occurring in aquatic photoautotrophs (Falkowski and Raven, 1997). UVR can have a fast induction of NPQ by increasing PSII inactivation, reducing RUBISCO activity and enhancing xanthophylls de-epoxidation (Van de Poll et al., 2009). So, NPQ increased as shorter UVR wavelengths were received by the cells (Fig. 4), but at the same time, photosynthetic carbon fixation and $Y$ decreased (Figs. 2 and 5). In our case, cells acclimated to HCa had higher NPQ values, at least during shortterm incubations, as compared to those under LCa (Fig. 4). Many studies have shown that NPQ and $F_{v}^{\prime} / F_{m}^{\prime}$ behave as mirror images, with increases in NPQ inversely correlated with decreases in $F_{v}^{\prime} / F_{m}^{\prime}$ (Adams III. and Demmig-Adams, 2004). Carotenoids involved in the xanthophylls cycle may also play an important role in maintaining the energy balance. This cycle has been shown to contribute to photoprotection under visible light by thermal dissipation of excess excitation energy (Demmig-Adams, 1990). Moreover, while UVR-induced reactive oxygen species (ROS) could damage lipids, DNA and proteins (He and Häder, 2002), carotenoids could scavenge singlet oxygen and other ROS (Bornman et al., 1997) thus allowing cells to reduce or minimize stress. Therefore, it is possible that the higher concentration of carotenoids in the HCa-grown cells might have partially helped them to cope with damaging UVR wavelengths. It is obvious that higher NPQ values coincided with higher calcification rates (Figs. 4 and 5), but overall NPQ values decreased with time in both $\mathrm{Ca}^{2+}$ treatments, and also with exposure to longer wavelength (Fig. 4). This implies that calcification plays a role as an alternative way to protect the cells from excessive energy. It is known that as an energy dependent process, calcification involves the cellular uptake of dissolved inorganic carbon and $\mathrm{Ca}^{2+}$ from the extracellular medium into the coccolith vesicle and the production of coccolith polysaccharides (Brownlee and Taylor, 2004).

After acclimation to the low $\mathrm{Ca}^{2+}$ concentration, calcification and photosynthesis at $20^{\circ} \mathrm{C}$ decreased by $81.3 \%$ and $55.4 \%$ (Fig. 5). Other studies (Herfort et al., 2002, 2004; Trimborn et al., 2007; Leonardos et al., 2009) however, found that low $\mathrm{Ca}^{2+}$ concentrations did not affect the POC production, photosynthetic carbon fixation or photosynthetic oxygen evolution. In addition, Trimborn et al. (2007) using SEM analysis found naked cells but not coccoliths or even residues, and they concluded that cells did not calcify at $0.1 \mathrm{mMCa}^{2+}$ concentrations. In general, it can be considered that calcite dissolution occurs when the calcite saturation state $(\Omega)$ is $<1$ (Trimborn et al., 2007). In our study, and although some part of the coccolith layer dissolved under the calcium carbonate undersaturated conditions $(\Omega<0.1)$, our SEM analysis of the LCa-grown cells showed that they did not lose the capacity to produce coccoliths (Fig. 1). In the case of our LCa cells, calcification decreased to $18.7 \%$ as compared to cells grown at ambient $\mathrm{Ca}^{2+}$ concentration (HCa, Fig. 5). Therefore, the LCa-grown cells might not need energy as much as the HCa-grown cells do to calcify due to reduced availability of $\mathrm{Ca}^{2+}$. Then photosynthetic activity were down-regulated, as reflected by the lower $Y$ and carbon fixation rates. A decrease in calcification rates in $E$. huxleyi is expected to decrease photosynthesis rates having a negative feedback that further reduces calcification. This is well consistent with the fact that no difference in the growth rates was found between the $\mathrm{LCa}$-grown and the $\mathrm{HCa}$-grown cells (Table 2), which reflected the net energy balance.

Cells grown at $\mathrm{LCa}$ and $\mathrm{HCa}$ displayed significant differences in the inhibition of $C / P$ (Figs. 5, 6 and 7). Moreover, the responses of photosynthesis and calcification towards UVR appear to be not synchronous. In this sense, Paasche (1966) found that calcification and photosynthesis of Emiliania huxleyi had different action spectra, as for example blue light appeared to be more efficient in calcification than in photosynthetic carbon fixation. In our study, and in agreement with a previous work (Gao et al., 2009), we showed no UVA impact on the $C / P$ ratio of $E$. huxleyi but a significant UVB-induced decrease of $C / P$. However, some differences might arise when considering the responses on more dense cultures (Guan and Gao, 2010) with shorter wavelengths of UVB causing more damage to photosynthesis than to calcification, and longer wavelengths of UVA resulting in a decrease of calcification; in general terms, large cell density affects the control of the carbonate system (Gattuso et al., 2010). The irradiance levels of PAR, UVA and UVB used by us in our experiments were respectively about 18.1, 43.6 and 
$60 \%$ of the maximum values measured in the South China Sea where coccolithophores are abundant (Ho et al., 2010; Li et al., 2011). Previous studies (Guan and Gao, 2010) indicated that $E$. huxleyi response changed with the irradiance and this was the base to use BWFs with an exposure response model based on irradiance (Neale and Kieber, 2000). The "chronic" and/or "dynamic" (i.e., reversible) effects would depend on the irradiance levels and the presence of threshold values above which any effects can be observed (Helbling et al., 1992). In addition, senescent and nutrient-limited cells tend to acquire extra layers of coccoliths (Paasche, 2002; Shiraiwa, 2003). Furthermore, and as previously mentioned, the coccolith layer around the cell surface could effectively reduce the transmission of UVB (Gao et al., 2009). Additionally, for E. huxleyi stain CS-369, both lowering $\mathrm{Ca}^{2+}$ concentration and elevated $\mathrm{CO}_{2}$ /decreased $\mathrm{pH}$ (Gao et al., 2009) led to a decrease in calcification. However, it is still unknown whether these two different ways have common mechanisms on regulation of calcification process.

The observed increase in photosynthesis of $\mathrm{HCa}$ cells under high temperature (Fig. 5) was similar to the results obtained by Feng et al. (2008). Photosynthetic carbon fixation is largely controlled by enzymes related to dark reactions (Falkwoski and Raven, 1997) and so its rate should also be temperature-dependent, with the enzymes involved in photosynthetic carbon fixation and calcification being stimulated by high temperatures. Additionally, phosphatase activity in E. huxleyi decreased with reduced $\mathrm{Ca}^{2+}$ concentrations as shown in a previous study (Shaked et al., 2006). Thus, if the enzymes of E. huxleyi were affected by long time acclimation to low $\mathrm{Ca}^{2+}$ concentration, this may have contributed to the different response of photosynthesis and calcification between two experimental $\mathrm{Ca}^{2+}$ concentrations (Fig. 5). In fact in our study, the calcification of E. huxleyi significantly increased at high temperatures (Fig. 5). However, Feng et al. (2008) did not observe such a significant effect of elevated temperature on calcification of this coccolithophore. Moreover, a $5^{\circ} \mathrm{C}$ increase in temperature (from 13 to $18^{\circ} \mathrm{C}$ ) decreased the calcification rate of $E$. huxleyi grown at both, present and future $\mathrm{CO}_{2}$ concentrations (De Bodt et al., 2010). It is likely that the differential responses of photosynthesis and calcification at different levels of temperature are responsible for such discrepancies, since photosynthetic carbon fixation process could be more sensitive to temperature as compared to calcification in this species. However, it can not be ruled out that specific responses among different strains, or counteracting effects due to differences in $\mathrm{pH}$ are also responsible for differences in responses to UVR even within the same species.

The ongoing ocean acidification is compounded with the shoaling of the mixed layer, increased surface seawater temperature and increased exposures of the cells to high radiation levels. Many studies focused on the effects of ocean acidification on coccolithophore (Riebesell et al., 2000; Feng et al., 2008; Iglesias-Rodriguez et al., 2008; De Bodt et al.,
2010), but few considered the role of UVR in natural conditions (Gao et al., 2009). Our results indicate that reduced calcification in E. huxleyi made the cells more vulnerable when they are exposed to excessive light energy even without UVR considered, since reduced calcification led to downregualated photoprotective capability. In addition, increased temperature decreased the $C / P$ ratio in the LCa-grown cells. Combined with the previous finding that reduced calcification led to enhanced sensitivity to UVR and decreased ratio of $C / P$ (Gao et al., 2009), the combined effects of ocean acidification, global warming and increased light and UVR exposures will synergistically reduce the $C / P$ ratio, which would eventually affect the carbon-related biogeochemical processes.

Acknowledgements. We thank the comments and suggestions of two anonymous reviewers that helped to improve this manuscript. This study was supported by National Basic Research Program of China (No. 2009CB421207), by program for Changjiang Scholars and Innovative Research Team (IRT0941) and by National Natural Science Foundation (No. 40930846, No. 40876058). VEV and EWH were supported by the Visiting Professor Program (111) from the Ministry of Education of China. This is Contribution No. 124 of Estación de Fotobiología Playa Unión.

Edited by: G. Herndl

\section{References}

Adams III., W. W. and Demmig-Adams, B.: Chlorophyll fluorescence as a tool to monitor plant response to the environment, in: Chlorophyll a Fluorescence: A Signature of Photosynthesis, edited by: Papageorgiou, G. C. and Govindjee, Springer, Berlin, Germany, 583-604, 2004.

Anning, T., Nimer, N., Merrett, M. J., and Brownlee, C.: Costs and benefits of calcification in coccolithophorids, J. Marine Syst., 9, 45-56, 1996.

Beardall, J., Sobrino, C., and Stojkovic, S.: Interactions between the impacts of ultraviolet radiation, elevated $\mathrm{CO}_{2}$, and nutrient limitation on marine primary producers, Photochem. Photobio. S., 8, 1257-1265, doi:10.1039/b9pp00034h, 2009.

Bornman, J. F., Reuber, S., Cen, Y., and Weissenböck, G.: Ultraviolet radiation as a stress factor and the role of protective pigments, in: Plants and UV-B: Responses to Environmental Change, edited by: Lumsden, P. J., Cambridge University Press, Cambridge, NY, 157-168, 1997.

Brownlee, C. and Taylor, A.: Calcification in coccolithophores: a cellular perspective, in: Coccolithophores: From Molecular Biology to Global Impact, edited by: Thierstein, H. R. and Young, J. R., Springer, Berlin, Germany, 31-49, 2004.

Brownlee, C., Davies, M., Nimer, N., Dong, L., and Merrett, M.: Calcification, photosynthesis and intracellular regulation in Emiliania huxleyi, B. Inst. Oceanogr. Monaco, 14, 19-35, 1995.

Buma, A. G. J., Van Oijen, T., Van de Poll, W., Veldhuis, M. J. W., and Gieskes, W. W. C.: The sensitivity of Emiliania huxleyi (Prymnesiophyceae) to ultraviolet-B radiation, J. Phycol., 36, 296-303, 2000. 
Cokacar, T., Kubilay, N., and Oguz, T.: Structure of Emiliania huxleyi blooms in the Black Sea surface waters as detected by SeaWIFS imagery, Geophys. Res. Lett., 28, 4607-4610, 2001.

De Bodt, C., Van Oostende, N., Harlay, J., Sabbe, K., and Chou, L.: Individual and interacting effects of $p \mathrm{CO}_{2}$ and temperature on Emiliania huxleyi calcification: study of the calcite production, the coccolith morphology and the coccosphere size, Biogeosciences, 7, 1401-1412, doi:10.5194/bg-7-1401-2010, 2010.

Demmig-Adams, B.: Carotenoids and photoprotection in plants: a role for the xanthophylls zeaxanthin, Biochim. Biophys. Acta, 1020, 1-24, 1990.

Dickson, A. G. and Millero, F. J.: A comparison of the equilibrium constants for the dissociation of carbonic acid in seawater media, Deep-Sea Res., 34, 1733-1743, 1987.

Falkowski, P. G. and Raven, J. A.: Aquatic Photosynthesis, Blackwell Scientific, Oxford, UK, 1997.

Feng, Y., Warner, M. E., Zhang, Y., Sun, J., Fu, F., Rose, J. M., and Hutchins, D. A.: Interactive effects of increased $\mathrm{pCO}_{2}$, temperature and irradiance on the marine coccolithophore Emiliania huxleyi (Prymnesiophyceae), Eur. J. Phycol., 43, 87-98, 2008.

Gao, K., Ruan, Z., Villafañe, V. E., Gattuso, J. P., and Helbling, E. W.: Ocean acidification exacerbates the effect of UV radiation on the calcifying phytoplankter Emiliania huxleyi, Limnol. Oceanogr., 54, 1855-1862, 2009.

Genty, B. E., Briantais, J. M., and Baker, N. R.: Relative quantum efficiencies of the two photosystems of leaves in photorespiratory and non-photorespiratory conditions, Plant Physiol. Bioch., 28, 1-10, 1989.

Guan, W. and Gao, K.: Impacts of UV radiation on photosynthesis and growth of the coccolithophore Emiliania huxleyi (Haptophyceae), Environ. Exp. Bot., 67, 502-508, 2010.

Gattuso, J. P., Gao, K., Lee, K., Rost, B., and Schulz, K. G.: Approaches and tools to manipulate the carbonate chemistry, in: Guide to best practices for ocean acidification research and data reporting, edited by: Riebesell, U., Fabry, V. J., Hansson, L., and Gattuso, J.-P., Publications office of the European Union, Luxembourg, 41-52, 2010.

Häder, D. P., Helbling, E. W., Williamson, C. E., and Worrest, R. C.: Effects of UV radiation on aquatic ecosystems and interactions with climate change, Photochem. Photobiol. Sci., 10, 242-260, 2011

He, Y. and Häder, D. P.: Reactive oxygen species and UV-B: effects on cyanobacteria, Photochem. Photobio. S., 1, 729-736, 2002.

Helbling, E. W., Villafañe, V. E., Ferrario, M. E., and Holm-Hansen, O.: Impact of natural ultraviolet radiation on rates of photosynthesis and on specific marine phytoplankton species, Mar. Ecol.Prog. Ser., 80, 89-100, 1992.

Herfort, L., Thake, B., and Roberts, R. J.: Acquisition and use of bicarbonate by Emiliania huxleyi, New Phytol., 156, 427-436, 2002.

Herfort, L., Loste, E., Meldrum, F., and Thake, B.: Structural and physiological effects of calcium and magnesium in Emiliania huxleyi (Lohmann) Hay and Mohler, J. Struct. Biol., 148, 307314, 2004

Ho, T. Y., Chou, W. C., Wei, C. L., Lin, F. J., Wong, G. T. F., and Lin, H. L.: Trace metal cycling in the surface water of the South China Sea: vertical fluxes, composition, and sources, Limnol. Oceanogr., 55, 1807-1820, 2010.

Iglesias-Rodriguez, M. D., Halloran, P. R., Rickaby, R. E. M., Hall,
I. R., Colmenero-Hidalgo, E., Gittins, J. R., Green, D. R. H., Tyrrell, T., Gibbs, S. J., von Dassow, P., Rehm, E., Armbrust, E. V., and Boessenkool, K. P.: Phytoplankton calcification in a high- $\mathrm{CO}_{2}$ world, Science, 320, 336-340, 2008.

Leonardos, N., Read, B., Thake, B., and Young, J. R.: No mechanistic dependence of photosynthesis on calcification in the coccolithophorid Emiliania huxleyi (Haptophyta), J. Phycol., 45, 10461051, 2009.

Lewis, E. and Wallace, D. W. R.: Program Developed for $\mathrm{CO}_{2}$ System Calculations, ORNL/CDIAC-105, Carbon Dioxide Information Analysis Center, Oak Ridge National Laboratory, US Department of Energy, Oak Ridge, Tennessee, 1998.

Li, G., Gao, K., and Gao, G.: Differential impacts of solar UV radiation on photosynthetic carbon fixation from the coastal to offshore surface waters in South China Sea, Photochem. Photobiol., 87, 329-334, 2011.

Mehrbach, C., Culberson, C. H., Hawley, J. E., and Pytkowicz, R. N.: Measurement of the appearent dissociation constants of carbonic acid in seawater at atmospheric pressure, Limnol. Oceanogr., 18, 897-907, 1973.

Mikaelyan, A. S., Pautova, L. A., Pogosyan, S. I., and Sukhanova, I. N.: Summer bloom of coccolithophorids in the northeastern Black Sea, Oceanology, 45 (Suppl. 1), S127-S138, 2005.

Milliman, J. D.: Production and accumulation of calcium carbonate in the ocean: Budget of a nonsteady state, Global Biogeochem. Cy., 7, 927-957, 1993.

Neale, P. J. and Kieber, D. J.: Assessing biological and chemical effects of UV in the marine environment: spectral weighting functions, in: Causes and Environmental Implications of Increased UV-B Radiation, edited by: Hester, R. E. and Harrison, R. M., The Royal Society of Chemistry, Cambridge, 61-83, 2000.

Nanninga, H. J. and Tyrrell, T.: Importance of light for the formation of algal blooms by Emiliania huxleyi, Mar. Ecol.-Progr. Ser., 136, 195-203, 1996.

Nimer, N. A., Merrett, M. J., and Brownlee, C.: Inorganic carbon transport in relation to culture age and inorganic carbon concentration in a high calcifying strain of Emiliania huxleyi, J. Phycol., 32, 813-818, 1996.

Paasche, E.: Action spectrum of coccolith formation, Physiol. Plant., 19, 770-779, 1966.

Paasche, E.: A review of the coccolithophorid Emiliania huxleyi (Prymnesiophyceae), with particular reference to growth, coccolith formation, and calcification photosynthesis interactions, Phycologia, 40, 503-529, 2002.

Pitsyk, G. K.: O kachestvennom sostave fytoplanktona Azovkogo moray (On the qualitiative compostion of phytoplankton in the Sea of Azov), Sevastopol' Biol. Sta. Trudy, 16, 71-89, 1963.

Porra, R. J.: The chequered history of the development and use of simultaneous equations for the accurate determination of chlorophylls a and b, Photosynth. Res., 73, 149-156, 2002.

Price, N. M., Harrison, G. I., Hering, J. G., Hudson, R. J., Nirel, P. M. V., Palenik, B., and Morel, F. M. M.: Preparation and chemistry of the artificial algal culture medium Aquil, Biol. Oceanogr., 6, 443-461, 1988/89.

Riebesell, U., Zondervan, I., Rost, B., Tortell, P. D., Zeebe, R. E., and Morel, F. M. M.: Reduced calcification of marine plankton in response to increased atmospheric $\mathrm{CO}_{2}$, Nature, 407, 364-367, 2000.

Rost, B. and Riebesell, U.: Coccolithophores and the biological 
pump: responses to environmental changes, in: Coccolithophores: From Molecular Biology to Global Impact, edited by: Thierstein, H. R. and Young, J. R., Springer, Berlin, Germany, 76-99, 2004.

Shaked, Y., Xu, Y., Leblanc, K., and Morel, F. M. M.: Zinc availability and alkaline phosphatase activity in Emiliania huxleyi: implications for Zn-P co-limitation in the ocean, Limnol. Oceanogr., 51, 299-309, 2006.

Shiraiwa, Y.: Physiological regulation of carbon fixation in the photosynthesis and calcification of coccolithophorids, Comp. Biochem. Phys. B., 136, 775-783, 2003.

Sikes, C. S. and Wilbur, K. M.: Function of coccolith formation, Limnol. Oceanogr., 27, 18-26, 1982.

Sikes, C. S., Roer, R. D., and Wilbur, K. M.: Photosynthesis and coccolith formation: inorganic carbon sources and net inorganic reaction of deposition, Limnol. Oceanogr., 25, 248-261, 1980.

Strickland, J. D. H. and Parsons, T. R.: A practical handbook of seawater analysis, B. Fish. Res. Board Can., 167, 49-80, 1972.
Trimborn, S., Langer, G., and Rost, B.: Effect of varying calcium concentrations and light intensities on calcification and photosynthesis in Emiliania huxleyi, Limnol. Oceanogr., 52, 22852293, 2007.

Van de Poll, H. W. and Buma, A. G. J.: Does ultraviolet radiation affect the xanthophyll cycle in marine phytoplankton?, Photochem. Photobio. S., 8, 1295-1301, 2009.

Villafañe, V. E., Sundbäck, K., Figueroa, F. L., and Helbling, E. W.: Photosynthesis in the aquatic environment as affected by UVR, in: UV Effects in Aquatic Organisms and Ecosystems, edited by: Helbling, E. W. and Zagarese, H. E., The Royal Society of Chemistry, Cambridge, 357-397, 2003.

Zondervan, I.: The effects of light, macronutrients, trace metals and $\mathrm{CO}_{2}$ on the production of calcium carbonate and organic carbon in coccolithophores - A review, Deep-Sea Res. Pt. II, 54, 521537, 2007. 